\title{
Different immersion periods and aqueous solutions effects upon the corrosion resistance of zinc and aluminium specimens
}

\author{
W.R. Osório*, C.M.A. Freire* and A. García*
}

\begin{abstract}
Several metallic materials form spontaneously an oxide film at the surface when is exposed in a corrosive environment. It is well known that the type of corrosive media may develop different results at the material corrosion resistance. The aim of the present paper is to investigate the influence of immersion periods and different solutions upon the corrosion resistance of pure $\mathrm{Zn}$ and $\mathrm{Al}$ specimens presenting different grain morphologies. The specimens were monitored for several periods in a $3 \% \mathrm{NaCl}$ solution at room temperature. Tests were also performed with variations of the $3 \% \mathrm{NaCl}$ solution modified by additions of acid and alkaline components. Both the electrochemical impedance spectroscopy (EIS) and polarization methods were applied.
\end{abstract}

Keywords Corrosion resistance. Immersion periods. Corrosive media. Zinc. Aluminium. EIS. Tafel.

\section{Efecto de las diferentes soluciones y tiempos de imersión en la resistencia a corrosión de las muestras de cinc y aluminio}

\begin{abstract}
Resumen Algunos materiales metálicos, cuando se encuentran en un entorno corrosivo, forman espontáneamente una película de óxido en su superficie. Se sabe que los medios corrosivos pueden dar resultados diferentes, según sea la resistencia a la corrosión del material. El propósito del siguiente trabajo es investigar la influencia de los períodos de inmersión en diferentes soluciones sobre la resistencia a la corrosión de probetas de cinc y aluminio puros, con morfologías de grano diferentes. Las probetas fueron ensayadas durante varios períodos de tiempo en soluciones de $\mathrm{NaCl} 3 \%$ y también con adiciones de ácidos y bases. Se utilizaron las técnicas de espectrometría de impedancia electroquímica (EIS) y de polarización.
\end{abstract}

Palabras clave Resistencia a corrosión. Períodos de inmersión. Medio corrosivo. Cinc. Aluminio. EIS. Tafel.

\section{INTRODUCTION}

The corrosion mechanism and corrosion behaviour for some metallic materials may be changed through active to the passive state when immersed in aggressive environment due to spontaneous oxide and/or hydroxide film formation. It has been reported that the oxide film grows when the metal is immersed either in acid, neutral or alkaline aqueous solutions. Obviously, the material corrosion behaviour considering both phenomena of oxide film formation and dissolution will present different performances depending on the characteristics of the solutions ${ }^{[1-3]}$. It was suggested that the role of the corrosion behaviour in passive metals is strongly dependent on the oxide film formation and dissolution as well on its composition, morphological formation and thickness ${ }^{[4-6]}$. As reported in previous papers, the electrolyte characteristic may affect the corrosion mechanism and corrosion behaviour $^{[3 \text { and } 7 \text { and } 8]}$. Obviously, there exist several other parameters affecting the materials corrosion behaviour $^{[9-12]}$.

\section{MATERIALS AND EXPERIMENTAL PROCEDURE}

Both commercially pure aluminum and zinc castings samples were obtained by using, respectively, a permanent steel mold which

(*) Department of Materials Engineering, State University of Campinas, UNICAMP, P.O. Box 6122, 13083 - 970 / Campinas, SP, Brazil. 
generates an equiaxed structure and a cooled vertical upward solidification system ${ }^{[13 \text { and } 14]}$ which generates a columnar structure. The chemical compositions for both pure metals were reported in a previous article ${ }^{[15]}$.

The working electrodes were ground by using a $600 \mathrm{SiC}$ grinding paper and immersed in a Pyrex glass container with $200 \mathrm{ml}$ of stagnant solution at room temperature. The specimens were kept in immersion in a $3 \% \mathrm{NaCl}$ solution and monitored for different periods: $20 \mathrm{~min}, 07 \mathrm{~d}(168 \mathrm{~h})$ and $15 \mathrm{~d}$ $(360 \mathrm{~h})$. After each immersion periods the EIS and Tafel polarization techniques were also conducted in $3 \% \mathrm{NaCl}$ and in modified $3 \% \mathrm{NaCl}$ solutions. In order to conduct the tests, a potentiostat coupled to a frequency analyser system, a glass corrosion cell kit with the working electrodes, a plate platinum counter-electrode and saturated calomel electrode (SCE) were used.
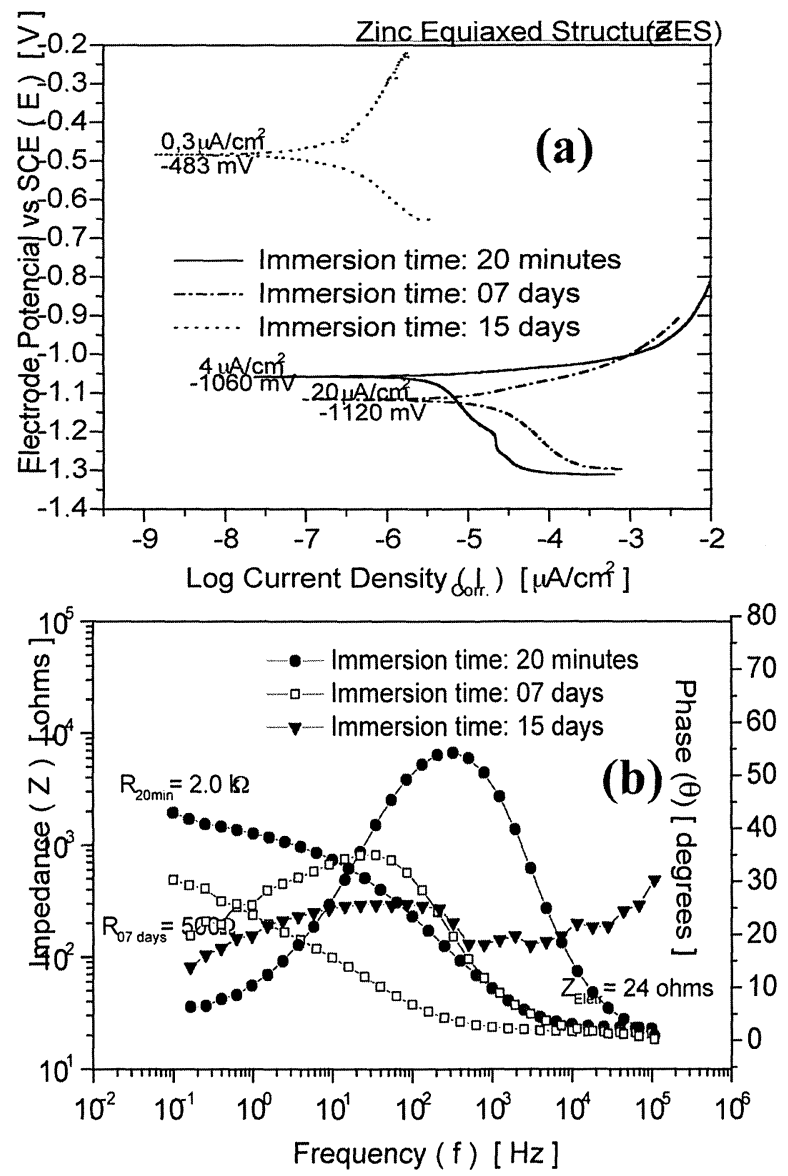

\section{RESULTS AND DISCUSSION}

Figures 1 and 2 show the results of polarization and EIS tests performed respectively with zinc $(\mathrm{Zn})$ and aluminium ( $\mathrm{Al}$ ) samples after different immersion periods.

A comparison is shown in figure 1 among the samples immersed for 20 min (impedance test) and those immersed for $7 \mathrm{~d}(168 \mathrm{~h})$ and $15 \mathrm{~d}(320 \mathrm{~h})$ both presenting oxide film formation: (a) and (b) show the comparison between different immersion times for the zinc equiaxed structure (ZES) and (c) and (d) for the zinc columnar structure (ZCE). By analyzing the results of the corrosion tests it is possible to observe that both types of structure immersed for $7 \mathrm{~d}$ have presented a considerable increase on the corrosion rate and a displacement of the corrosion potential toward the less noble side. On the other hand, both zinc structures
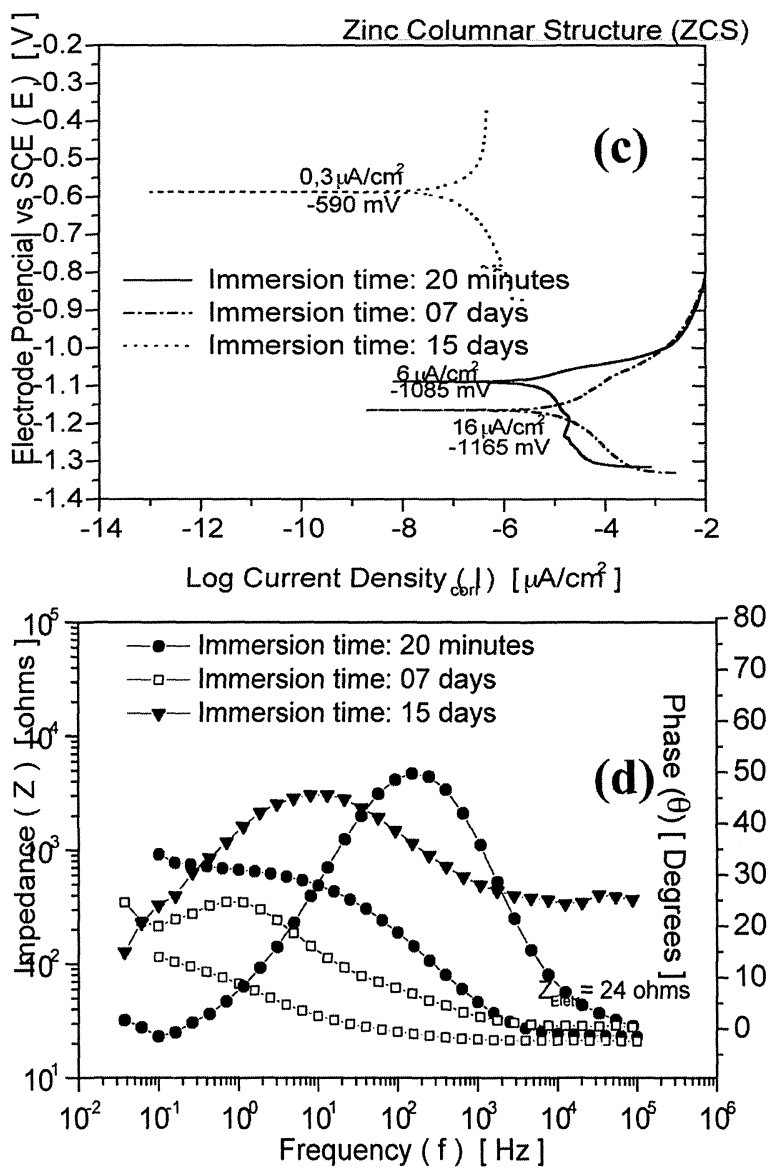

Figure 1. Comparison between polarization curves (a) and (c) and EIS graphs (b) and (d) performed respectively with Zinc equiaxed (ZES) and columnar structure (ZCS) immersed in a $3 \% \mathrm{NaCl}$ solution after different immersion periods.

Figura 1. Comparación entre las curvas de la polarización (a) y (c) y los gráficos de EIE (b) y (d) realizados, respectivamente, para las estructuras del cinc equiaxial (ZES) y columnar (ZCS) en inmersión en $3 \% \mathrm{NaCl}$ después de diferentes tiempos de inmersión. 
Different immersion periods and aqueous solutions effects upon the corrosion resistance of zinc and aluminium specimens W.R. OSÓRIO, C.M.A. FREIRE AND A. GARCÍA
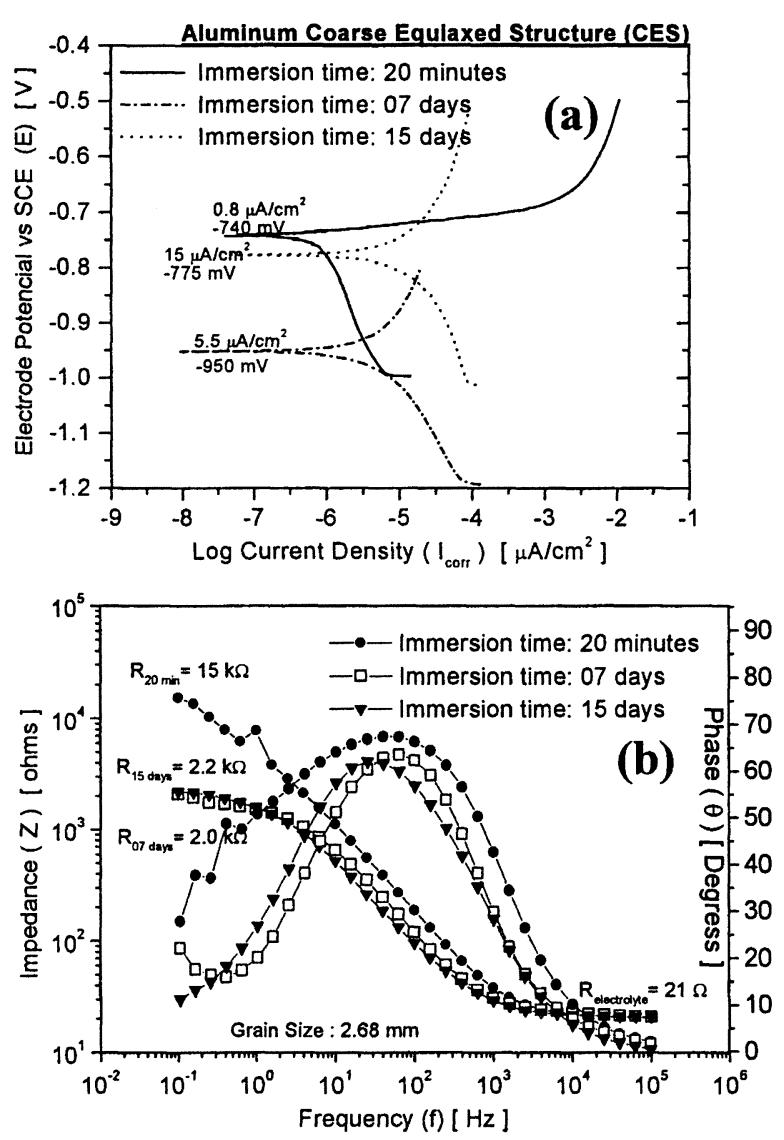
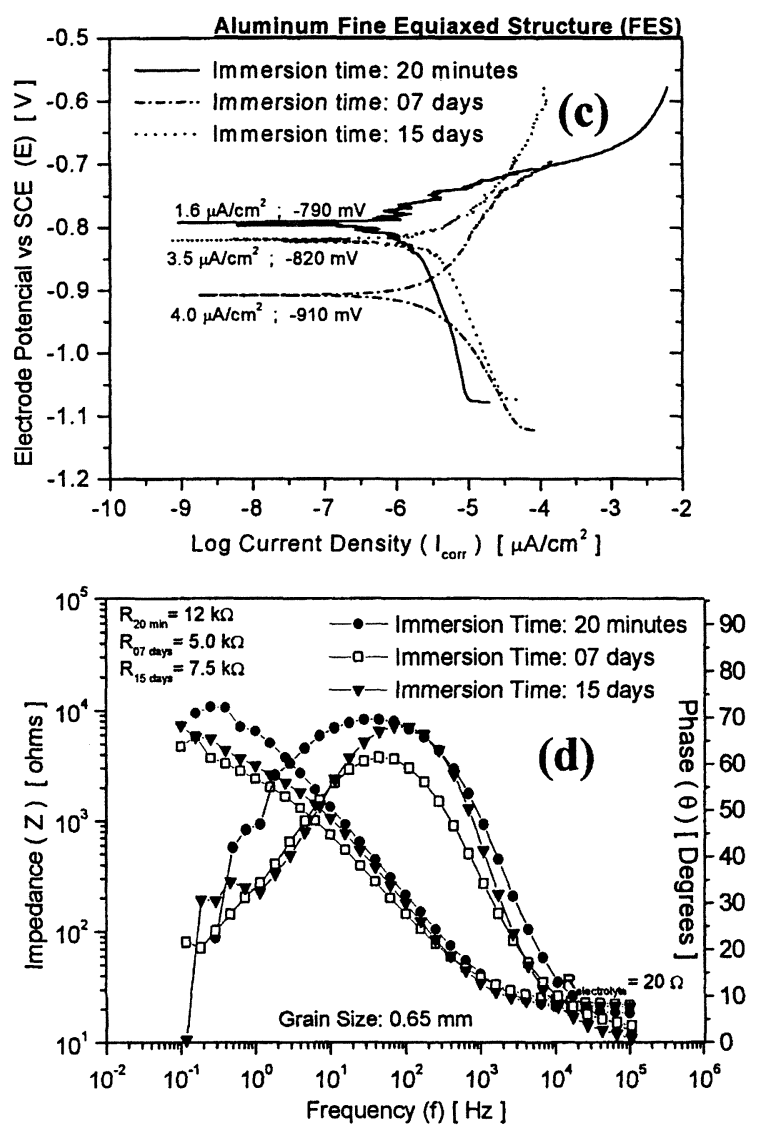

Figure 2. Comparison between polarization curves (a) and (c) and EIS graphs (b) and (d) performed respectively with aluminium coarse equiaxed (CES) and fine equiaxed structure (FES) immersed in a $3 \% \mathrm{NaCl}$ solution after different immersion periods.

Figura 2. Comparación entre las curvas de la polarización (a) y (c) y los gráficos de EIE (b) y (d) realizados respectivamente para las estructuras del aluminio equiaxial grosera (CES) y equiaxial refinada (FES) en inmersión en $3 \% \mathrm{NaCl}$ después de diferentes tiempos de inmersión.

immersed for $15 \mathrm{~d}$ have shown a considerable decrease on the corrosion rate and displacement of the corrosion potential toward the more noble side than those immersed for $7 \mathrm{~d}$. These results permit to conclude that ZES presents a better corrosion behavior than ZCS ${ }^{[16]}$ due to oxide film formation.

Figure $2(\mathrm{a}-\mathrm{d})$ exhibits, a comparison between the aluminum coarse equiaxed (CES) and the fine equiaxed structures (FES).

The results presented in figure 2 show that the role of the immersion time upon corrosion behaviour for the aluminium specimens is similar to that observed for zinc specimens. It can also be observed an increase in the corrosion rate for an immersion period of $7 \mathrm{~d}$ and a decrease after a period of $15 \mathrm{~d}$ and a displacement of the corrosion potential toward the more noble side for both immersion periods due to oxide film formation.
Figure 3 shows a comparison of the corrosion behaviour of $\mathrm{Al}$ and $\mathrm{Zn}$ samples submitted to 4 different compositions: a basic $3 \% \mathrm{NaCl}$ solution; and modifications of this solutions obtained by adding $0.05 \%$ acetic acid, $0.05 \%$ hydrochloride acid and $0.5 \%$ sodium hydroxide, respectively. It can be seen that both metals present a lower corrosion resistance in the alkaline solution (3\% $\mathrm{NaCl}+0.5 \% \mathrm{NaOH})$. Aluminium samples had their corrosion resistance decreased with tests performed in both acidified solutions. However, the more significant decrease is observed in presence of $\mathrm{Cl}^{-}$ions. The zinc samples have presented a smaller corrosion rate in presence of $\mathrm{Cl}^{-}$ions than in $\mathrm{COOH}^{-}$ions, as is the case of $\mathrm{HCl}$ and acetic acid respectively.

Figure 4 shows micrographs of the oxide layers of zinc and aluminium samples which are corrosion products basically composed by $\mathrm{ZnO}$ and $\mathrm{Zn}(\mathrm{OH})_{2}{ }^{[17-19]}$ and $\mathrm{Al}_{2} \mathrm{O}_{3}$ and $\mathrm{Al}(\mathrm{OH})_{3}{ }^{[18 \text { and } 19]}$. 

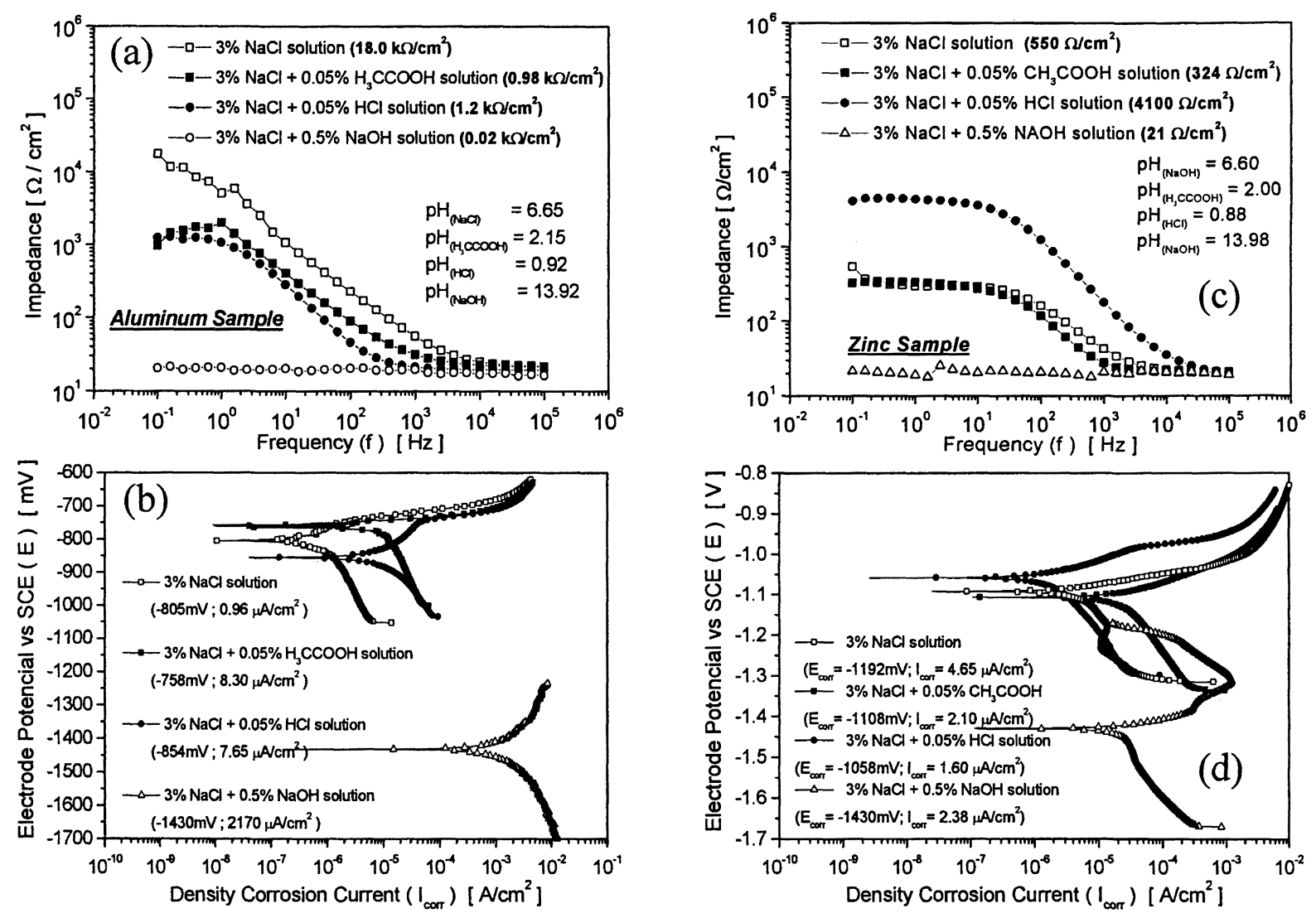

Figure 3. Influence of the electrolyte upon the corrosion behavior of $\mathrm{Al}$ ( $\mathrm{a}$ and b) and $\mathrm{Zn}$ samples c and d).

Figura 3. Influencia del electrolito en la resistencia corrosión de las muestras de Al (a y b) y Zn (c y d).

In figure 4 , it can be seen that both zinc and aluminium coarser structures present a more homogeneous oxide layers than finer structures, indicating a higher influence upon the corrosion rate and corrosion potential. Zinc specimens have taken about $7 \mathrm{~d}$ to start the reaction against the corrosion phenomena. After this time, zinc samples have presented a reversion in behaviour, i.e., a decrease in corrosion rate and the displacement of the corrosion potential toward the noble side. On the other hand, aluminium samples clearly have taken more than $15 \mathrm{~d}$ to achieve its electrochemical reaction against the corrosion process. In general, each type of structural morphology has generated corrosion layers of different textures. The coarser structure has formed a more homogeneous corrosion product layer, a lower corrosion rate and its corrosion potential displaced toward the more noble side.

\section{CONCLUSIONS}

All zinc and aluminium specimens immersed for $168 \mathrm{~h}$ in a $3 \% \mathrm{NaCl}$ solution have presented a significant decrease in its corrosion resistances when compared with the results of tests performed in a period of $20 \mathrm{~min}$, independently of the structural morphology.

Aluminium and zinc samples with coarser grain sizes exhibited more homogeneous oxide films and apparently free of porosity than the finer grain samples.

The corrosion kinetics was strongly influenced by electrolyte characteristics such as the presence of chlorides ions which can change considerably the corrosion behaviour for both metals.

\section{Acknowledgements}

The authors acknowledge financial support provided by FAEP-UNICAMP, FAPESP and CNPq.

\section{REFERENCES}

[1] D. Weng, P. Jokiel, A. Uebleis and H. Boehni, Surf. Coat. Technol. 88 (1996) 147-156. 


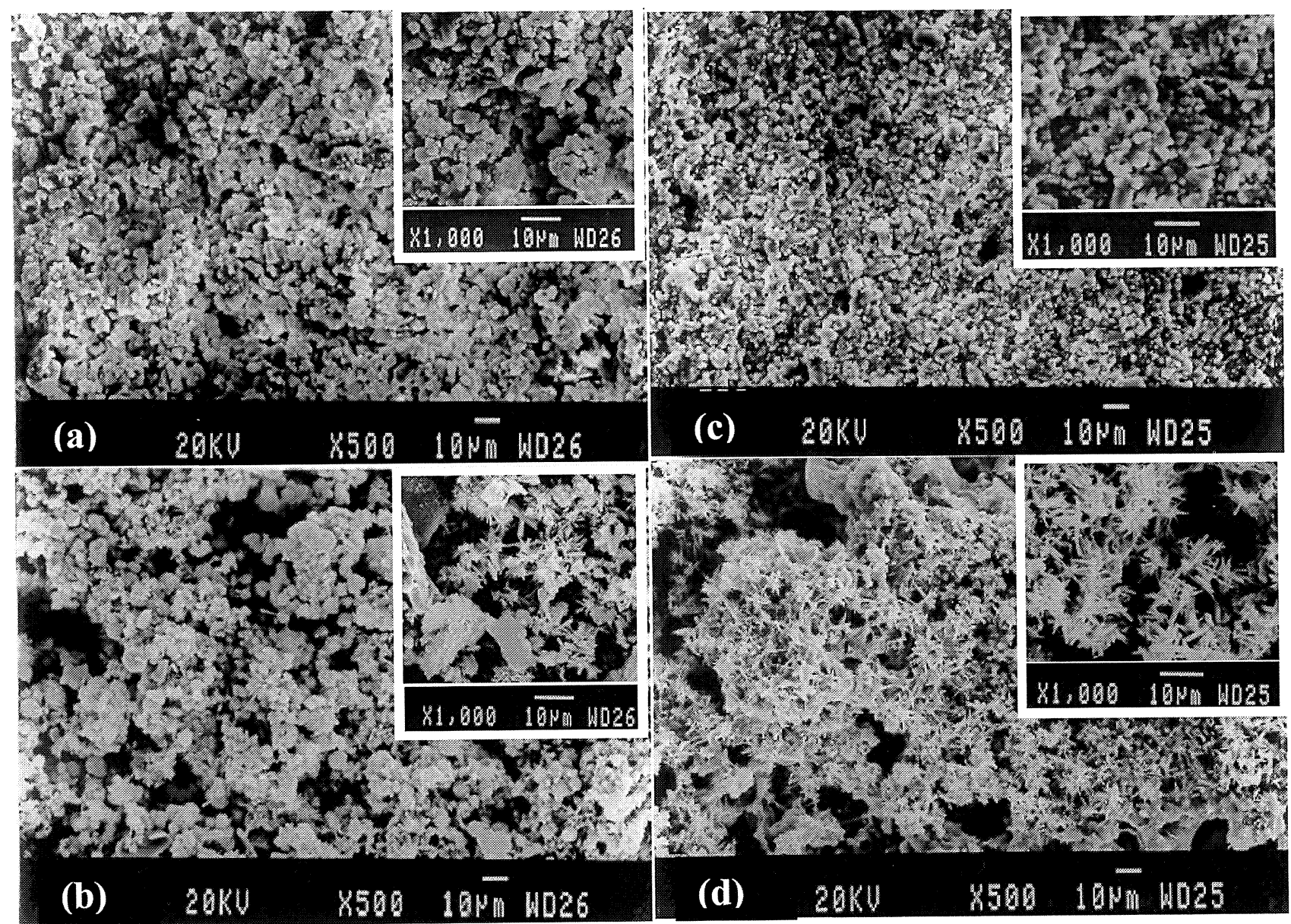

Figure 4. SEM micrographs of aluminum coarser ( $a$ ) and finer equiaxed (b) and zinc coarser equiaxed (c) and finer structure (d) after immersion in a $3 \% \mathrm{NaCl}$ solution. Each micrograph presents in upper-right side a magnification of 1000 times.

Figura 4. Microscopia electrónica de estructuras del Al equiaxial refinada (a) y equiaxial grosera (b) y estructuras del Zn grosera (c) y refinada (d) después de inmersión en solución $3 \% \mathrm{NaCl}$. Las micrografias presentan una ampliación del $1000 X$.

[2] S.M. Moon and S.I. Pyun, Corr. Sci. 39 (1997) 399-408.

[3] S. Magaino, M. Soga, K. Sobue, A. Kawaguchi, N. ISHIDA and H. IMAI, Electrochem. Acta 44 (1999) 43074312.

[4] S.I. Pyun, Mater. Lett. 27 (1996) 297-305.

[5] I. Serebrennikova, P. VAn?sek and V.I. Birss, Electrochem. Acta 42 (1997) 145-151.

[6] H. Park and J.A. SzPunar, Corros. Sci. 40 (1998) 525 545.

[7] A.V. Benedetti, P.L. Cabot, J.A. Garrido and A.H. Moreira, Electrochem. Acta 45 (2000) 2187-2195.

[8] N.R. Short, S. ZHOU and J. K. Dennis, Surf. Coat. Technol. 79 (1996) 218-224.

[9] A.M. Olmedo, M. Villegas and M.G. Alvarez, J. Nucl. Mater. 229 (1996) 102-114.

[10] T. Murai, T. IsObE and Y. MaE, J. Nucl. Mater. 230 (1996) 178-180.

[11] C.M. Abreu, Mj Cristobal, P. Merino, X.R Novoa, G. PenA and M.C. Perez, Rev. Metal. Madrid 38 (2002) 315 325.
[12] L.S. Hernandez, J.M. Miranda and O. Dominguez, Rev. Metal. Madrid 38 (2002) 108-116.

[13] W.R. Osório and A. García, Mater. Sci. Eng. A 325 (2002) 103-111.

[14] C.A. Sigueira, N. Cheung and A. García, Metall. Mater. Trans. 33 A (2002) 2107-2118.

[15] W.R. Osório, C.A. Siqueira, C.M.A. Freire and A. García, Proc. Conf. Mater. Sci. Technol., CTM 2003, Madrid, Spain, 2003

[16] W.R. Osório, C.M.A. Freire and A. García, Mater. Sci. Eng. 402A (2005) 22-32.

[17] I.O. Wallinder, W. He, P-E. Augustsson and C. LEYGRAF, Corros. Sci. 41 (1999) 2229-2249.

[18] X. Zhang, S. Lo-Russo, A. Miotello, L. Guzmán, E. Cattaruzza, P.L. Bonora and L. Benedetti, Surf. Coat. Technol. 141 (2001)187-193.

[19] Y. LI, Corros. Sci. 43 (2001) 1793-1800. 